\title{
Top 100 most-cited articles on intraoral squamous cell carcinoma and its risk factors: a bibliometric study
}

\author{
Gilberto MELO(a) (iD \\ Carolina Simão FLAUSINO(a) \\ Isadora Koepp DARELLA ${ }^{(b)}$ (iD \\ Andressa Fernanda Paza \\ MIGUEL(a) iD \\ Paulo Antônio \\ MARTINS-JÚNIOR ${ }^{(c)}$ \\ Elena Riet Correa RIVERO(d)
}

(a) Universidade Federal de Santa Catarina UFSC, Postgraduate Program in Dentistry, Federal University of Santa Catarina, Florianópolis, SC, Brazil.

(b) Universidade Federal de Santa Catarina UFSC, Dental School, Florianópolis, SC, Brazil.

(c) Universidade Federal de Minas Gerais UFMG, Department of Paediatric Dentistry, Belo Horizonte, MG, Brazil.

(d) Universidade Federal de Santa Catarina UFSC, Health Sciences Center, Department of Pathology, Florianópolis, SC, Brazil.

Declaration of Interests: The authors certify that they have no commercial or associative interest that represents a conflict of interest in connection with the manuscript.

Corresponding Author:

Elena Riet Correa Rivero

E-mail: riet.elena@gmail.com

https://doi.org/10.1590/1807-3107bor-2022.vol36.0030

Submitted: April 2, 2021

Accepted for publication: November 3, 2021

Last revision: November 24, 2021

\begin{abstract}
This study aimed to analyze the 100 most-cited articles on intraoral squamous cell carcinoma and its risk factors. A literature search was conducted on November 12, 2020 using the Web of Science database. Bibliometric data were collected after study selection. Bibliometric maps were generated using VOSviewer software. Articles were ranked based on the number of citations, ranging from 108 to 1513 per study. Eleven studies presented at least 400 citations. Articles were published between 1950 and 2017 and were mostly case-control studies $(n=39)$ and narrative reviews $(n=29)$. The author and institution in most articles were S. Franceschi $(n=10)$ and the International Agency for Research on Cancer $(n=10)$, respectively. The most prominent countries were the United States $(n=35)$, the United Kingdom ( $(=16)$, and France $(n=9)$. Among the 100 most-cited articles, only one article was from Brazil, and the authors were affiliated with the Ludwig Institute for Cancer Research. Bibliometric maps showed strong associations between the terms alcohol, smoked/smokeless tobacco, and human papillomavirus. Emerging terms, such as areca nut and betel quid, were cited in recent articles. In conclusion, alcohol, tobacco, and human papillomavirus were the most prominent risk factors. Case-control design was the most common study design, and the majority of studies were conducted in the United States by the International Agency for Research on Cancer.
\end{abstract}

Keywords: Bibliometrics; Mouth Neoplasms; Alcohol Drinking; Areca; Epidemiologic Factors; Tobacco Products; Research Design.

\section{Introduction}

Approximately $90 \%$ of all intraoral malignancies are squamous cell carcinomas (SCCs), which are solid tumors originating from abnormal epithelial cells. ${ }^{1}$ Tobacco smoking is considered a major etiological factor for intraoral SCC development, and although the harms associated with its carcinogenic potential are known, smoking is widely accepted as part of daily life. ${ }^{2}$ Alcohol intake is also proposed as a risk factor for intraoral SCC, and although evidence does not support an association between isolated alcohol consumption and malignant transformation, ${ }^{3}$ its synergistic consumption with tobacco products (both smoked and smokeless) can significantly increase the odds for intraoral SCC development. ${ }^{4}$ Moreover, 
smokeless tobacco products result in prolonged exposure due to direct contact with the oral mucosa and mixture with saliva, which consequently leads to higher absorption of carcinogens. ${ }^{5}$

The consumption of smokeless tobacco is also often associated with the consumption of areca nuts and betel leaves, a habit deeply entrenched in the endemic regions of southern Asia due to its pleasing psychostimulatory effects. ${ }^{6}$ The mixture of areca nut, slaked lime, and betel leaf (combined or not with tobacco) is known as betel quid, which is also used in regional variations such as gutka, pan masala, and naswar. ${ }^{7}$ Although the cancer-promoting effects of these substances are attributable to their association with tobacco, the consumption of some of these products (such as areca nut chewing) can constitute an individual risk factor. ${ }^{8}$

Intraoral SCC has been linked to not only deleterious habits but also (to a greater or less extent) viral infections, especially those related to the human papillomavirus (HPV); ${ }^{9}$ oral health status; ${ }^{10}$ geographic/socioeconomic variables, ${ }^{11}$ environmental/ occupational exposures; ${ }^{12}$ and familial history. ${ }^{13}$ In this context, a bibliometric analysis of the most-cited articles on intraoral SCC and its risk factors can help clinicians and researchers identify prominent authors, countries, journals, and institutions with high publishing activity and also measure research trends over time. ${ }^{14}$

Therefore, this study aimed to assess the top 100 most-cited articles on intraoral SCC and its risk factors, focusing on bibliometric measures to better understand the influence and dissemination of different types of studies across the scientific community.

\section{Methodology}

This study was exempted from ethical approval and patient consent since it was based on secondary data and did not directly involve human participants.

\section{Information sources}

On November 12, 2020, bibliometric analysis focused on the 100 most-cited articles on intraoral SCC and its risk factors was conducted in the Web of Science Core Collection database. The complete search strategy is shown in Table 1.

\section{Eligibility criteria and study selection}

On the same day of the search, four authors simultaneously performed title and abstract reading

Table 1. Database search strategy.

TS = "oral squamous cell carcinoma" OR "oral squamous cell carcinomas" OR "intraoral squamous cell carcinoma" $O R$ "intraoral squamous cell carcinomas" OR "intra-oral squamous cell carcinoma" OR "intra-oral squamous cell carcinomas" OR "mouth squamous cell carcinoma" OR "mouth squamous cell carcinomas" OR "buccal squamous cell carcinoma" OR "buccal squamous cell carcinomas" OR "tongue squamous cell carcinoma" OR "tongue squamous cell carcinomas" OR "oral cancer" OR "oral cancers" OR "oral cavity cancer" OR "oral cavity cancers" OR "oral malignancy" OR "oral malignancies" OR "oral cavity malignancy" OR "oral cavity malignancies" OR "oral carcinoma" OR "oral carcinomas" OR "oral cavity carcinoma" OR "oral cavity carcinomas" OR "buccal cancer" OR "buccal cancers" OR "buccal carcinoma" OR "buccal carcinomas" OR "mouth cancer" OR "mouth cancers" OR "mouth carcinoma" OR "mouth carcinomas" OR "tongue cancer" OR "tongue cancers" OR "tongue carcinoma" OR "tongue carcinomas" OR "cancer of mouth" OR "cancer of the mouth" OR "carcinoma of mouth" OR "carcinoma of the tongue"

Web of Science Core Collection (Filters: Article and Review)
OR "carcinoma of tongue" OR "OSCC" OR "oral SCC" OR "buccal SCC" OR "mouth SCC" OR "tongue SCC") AND $\mathrm{TS}=$ ("tobacco" OR "cigar" OR "cigars" OR "cigarette" OR "cigarettes" OR "cigarillo" OR "cigarillos" OR "bidi" OR "bidis" OR "beedi" OR "beedis" OR "smokers" OR "smoker" OR "smoking" OR "smoked" OR "gutka" OR "gutkas" OR "ghutka" OR "gutkha" OR "snuff" OR "snus" OR "paan" OR "betel quid" OR "dokha" OR "hookah" OR "narghile" $O R$ "arghilé" OR "waterpipe" OR "water pipe" OR "water-pipe" OR "hubble-bubble" OR "shisha" OR "nicotin" OR "e-cigarette" OR "e-liquid" OR "e-cig" OR "areca" OR "human papilloma virus" OR "HPV" OR "risk factor" OR "risk factors" OR "ethanol" OR "alcohol" OR "alcohols" OR "alcoholism" OR "alcoholic" OR "alcoholics" OR "naswar" OR "mishri" OR "masher" OR "tuibur" OR "hidakphu" OR "gul" OR "mawa" OR "khaini" OR "pan masala" OR "zarda" OR "tambaku" OR "hogesoppu" OR "gnudi" OR "kadapa" OR "mainpuri" OR "qiwam" OR "kimam" OR "dohra" OR "EBV" OR "epstein-barr virus" OR "occupational disease" OR "occupational exposure" OR "periodontal disease" OR "tooth loss" OR "missing teeth" OR "alveolar bone loss" OR "clinical attachment loss" OR "periodontitis" OR "oral hygiene" OR "dental status" OR "maté" OR "mate" OR "chimarrao" OR "ilex paraguariensis" OR "tereré" OR "terere" OR "yerba-maté" OR "yerba-mate" OR "mates" OR "matés" OR (("mouth rinse" OR "mouthwash" OR "mouthwashes") AND ("acetaldehyde" OR "ethanol" OR "alcohol"))) 
of the identified articles, and if necessary, full-text reading was conducted. Articles were organized in descending order based on the number of citations. Literature screening was stopped when the top 100 most-cited articles related to the investigated topic were identified; if a draw occurred, an article with a higher citation density (mean citations per year) was selected.

Moreover, the following exclusion criteria were applied: a) studies that did not investigate the occurrence of intraoral SCC and its risk factors; b) studies that assessed other anatomical locations (in which results were not separately reported for the intraoral region); $c$ ) studies assessing geographic distribution or incidence/mortality trends of oral cancer; d) narrative reviews on general aspects of oral cancer (i.e., not focused on risk factors or not presenting at least a dedicated topic); and e) case reports, protocols, short communications, personal opinions, letters, posters, conference abstracts, and laboratory research (in vivo and in vitro studies). There were no restrictions on publication year, language, or number of authors.

\section{Data collection process and data items}

The following data were extracted: full authors' list, corresponding author details (name, country, continent, and institution), article title, title of the scientific journal, keywords, study design, and number of citations. Moreover, the citation density was calculated based on the mean number of citations per year.

To avoid issues with multiple affiliations, only information on the corresponding authors was considered. Affiliations were based on the correspondence address at the time the article was published (regardless of whether the same author reported another correspondence address in previous or subsequent studies). For most articles, related data were automatically generated by Web of Science, although for articles for which this information was not generated, we manually extracted data from the corresponding full-text according to the same criteria. If the corresponding author was not indicated, data were collected considering the first affiliation of the first author.
The study designs were categorized based on the definitions proposed by Grant et al. ${ }^{15}$ as follows: case-control, cohort, cross-sectional, narrative review, systematic review (i.e., presents a comprehensive literature search, explicit eligibility criteria, and formal critical appraisal of the included studies), and systematized review (i.e., presents features of a systematic review but does not attend all methodological requisites). Key terms to categorize risk factors from each included article (e.g., alcohol intake, smoked/smokeless tobacco, dietary factors, and oral health) were also assigned. If discrepancies arose, data were double-checked by all researchers. Additionally, to assess the contribution of non-indexed research to the citation count, the number of citations from Scopus and Google Scholar were manually extracted considering the top 15 most-cited articles.

\section{Synthesis of results and statistical analysis}

Data were tabulated and analyzed using Excel 2016 (Microsoft Office 2016, Microsoft Corporation, United States [US]). The Shapiro-Wilk test was used to assess the data distribution. Since the data were not normally distributed, Spearman's rank correlation coefficient test was used. The significance level was set at $5 \%$. Statistical analyses were performed using SPSS (version 25, IBM, US), and VOSviewer software (version 1.6.16, Centre for Science and Technology Studies, Leiden University, Netherlands) was used to generate bibliometric graphics.

\section{Results}

Approximately 25000 studies were identified. Among the 260 studies screened, 160 were excluded. The list with the top 100 most-cited articles along with the number of citations and citation density from WoS-CC is presented in Table 2.

The included articles received 21671 citations in WoS-CC, ranging from 108 to 1513 citations per study. Eleven articles received more than 400 citations and could be considered citation classics. The remaining 89 articles received less than 400 citations, among which $69.6 \%$ received between 100 and 200 citations, $28 \%$ received between 200 and 300 citations, and $2.25 \%$ received between 300 and 400 citations. Self-citations 
Table 2. The 100 most-cited articles concerning intraoral squamous cell carcinoma and its associated factors. The articles are ranked based on the number of citations in Web of Science Core Collection and data are presented as rank, full reference, number of citations, and citation density.

\begin{tabular}{|c|c|c|c|}
\hline Rank & Reference & Citations & $\begin{array}{l}\text { Citation } \\
\text { density* }\end{array}$ \\
\hline 1 & $\begin{array}{l}\text { Warnakulasuriya S. Global epidemiology of oral and oropharyngeal cancer. Oral Oncology. } \\
\text { 2009;45(4-5):309-16. https://doi.org/10.1016/i.oraloncology.2008.06.002. }\end{array}$ & 1,513 & 137.55 \\
\hline 2 & $\begin{array}{l}\text { Herrero R, Castellsague X, Pawlita M, Lissowska J, Kee F, Balaram P, et al. Human papillomavirus and oral } \\
\text { cancer: the International Agency for Research on Cancer multicenter study. Journal of the National Cancer } \\
\text { Institute. 2003;95(23):1772-83. https://doi.org/10.1093/jnci/dig/107. }\end{array}$ & 837 & 49.24 \\
\hline 3 & $\begin{array}{l}\text { Neville BW, Day TA. Oral cancer and precancerous lesions. CA-A Cancer Journal For Clinicians. } \\
\text { 2002;52(4):195-215. https://doi.org/10.3322/caniclin.52.4.195. }\end{array}$ & 647 & 35.94 \\
\hline 4 & $\begin{array}{l}\text { Bhaskaran K, Douglas I, Forbes H, dos-Santos-Silva I, Leon DA, Smeeth L. Body-mass index and } \\
\text { risk of } 22 \text { specific cancers: a population-based cohort study of } 5.24 \text { million UK adults. Lancet. } \\
2014 ; 384(9945): 755-65 \text {. https://doi.org/10.1016/S0140-6736(14)60892-8. }\end{array}$ & 636 & 106.00 \\
\hline 5 & $\begin{array}{l}\text { Mork J, Lie AK, Glattre E, Clark S, Hallmans G, Jellum E, et al. Human papillomavirus infection as a risk factor } \\
\text { for squamous-cell carcinoma of the head and neck. New England Journal of Medicine. 2001;344(15):1 125-31. } \\
\text { https://doi.org/10.1056/NEJM200104123441503. }\end{array}$ & 625 & 32.89 \\
\hline 6 & $\begin{array}{l}\text { Hashibe M, Brennan P, Benhamou S, Castellsague X, Chu C, Curado MP, et al. Alcohol drinking in never users } \\
\text { of tobacco, cigarette smoking in never drinkers, and the risk of head and neck cancer: pooled analysis in the } \\
\text { International Head and Neck Cancer Epidemiology Consortium. Journal of the National Cancer Institute. } \\
\text { 2007;99(10):777-89. https://doi.org/10.1093/inci/djk179. }\end{array}$ & 576 & 44.31 \\
\hline 7 & $\begin{array}{c}\text { Hashibe M, Brennan P, Chuang SC, Boccia S, Castellsague X, Chen C, et al. Interaction between tobacco } \\
\text { and alcohol use and the risk of head and neck cancer: pooled analysis in the International Head and Neck } \\
\text { Cancer Epidemiology Consortium. Cancer Epidemiology Biomarkers \& Prevention. 2009;18(2):541-50. } \\
\text { https://doi.org/10.1 158/1055-9965.EPI-08-0347. }\end{array}$ & 556 & 50.55 \\
\hline 8 & $\begin{array}{l}\text { Ko YC, Huang YL, Lee CH, Chen MJ, Lin LM, Tsai CC. Betel quid chewing, cigarette-smoking and } \\
\text { alcohol-consumption related to oral-cancer in Taiwan. Journal of Oral Pathology \& Medicine. } \\
\text { 1995;24(10):450-3. https://doi.org/10.1111/j.1600-0714.1995.tb01 132.x. }\end{array}$ & 516 & 20.64 \\
\hline 9 & $\begin{array}{c}\text { Winn DM, Blot WJ, Shy CM, Pickle LW, Toledo A, Fraumeni JF. Snuff dipping and oral-cancer among } \\
\text { women in the southern United States. New England Journal of Medicine. 1981;304(13):745-9. } \\
\text { https://doi.org/10.1056/NEJM198103263041301. }\end{array}$ & 474 & 12.15 \\
\hline 10 & $\begin{array}{l}\text { Rothman K, Keller A. Effect of joint exposure to alcohol and tobacco on risk of cancer of mouth and pharynx. } \\
\text { Journal of Chronic Diseases. 1972;25(12):71 1-6. https://doi.org/10.1016/0021-9681 (72)90006-9. }\end{array}$ & 413 & 8.60 \\
\hline 11 & $\begin{array}{l}\text { Schwartz SM, Daling JR, Doody DR, Wipf GC, Carter JJ, Madeleine MM, et al. Oral cancer risk in relation } \\
\text { to sexual history and evidence of human papillomavirus infection. Journal of the National Cancer Institute. } \\
\qquad 1998 ; 90(21): 1626-36 . \text { https://doi.org/10.1093/inci/90.21.1626. }\end{array}$ & 410 & 18.64 \\
\hline 12 & $\begin{array}{l}\text { Boffetta P, Hecht S, Gray N, Gupta P, Straif K. Smokeless tobacco and cancer. Lancet Oncology. } \\
\text { 2008;9(7):667-75. https://doi.org/10.1016/S1470-2045(08)70173-6. }\end{array}$ & 337 & 28.08 \\
\hline 13 & $\begin{array}{l}\text { Miller CS, Johnstone BM. Human papillomavirus as a risk factor for oral squamous cell carcinoma: a } \\
\text { meta-analysis, } 1982-1997 \text {. Oral Surgery Oral Medicine Oral Pathology Oral Radiology and Endodontology. } \\
2001 ; 91(6): 622-35 \text {. https://doi.org/10.1067/moe.2001.115392. }\end{array}$ & 295 & 15.53 \\
\hline 14 & $\begin{array}{c}\text { Silverman S. Demographics and occurrence of oral and pharyngeal cancers - the outcomes, } \\
\text { the trends, the challenge. Journal of the American Dental Association. 2001;132:7S-11S. } \\
\text { https://doi.org/10.14219/jada.archive.2001.0382. }\end{array}$ & 291 & 15.32 \\
\hline 15 & $\begin{array}{c}\text { Llewellyn CD, Johnson NW, Warnakulasuriya S. Risk factors for squamous cell carcinoma of the oral } \\
\text { cavity in young people - a comprehensive literature review. Oral Oncology. 2001;37(5):401-18. } \\
\text { https://doi.org/10.1016/S1368-8375(00)00135-4. }\end{array}$ & 290 & 15.26 \\
\hline 16 & $\begin{array}{l}\text { Mashberg A, Boffetta P, Winkelman R, Garfinkel L. Tobacco smoking, alcohol-drinking, and cancer } \\
\text { of the oral cavity and oropharynx among United-States veterans. Cancer. 1993;72(4):1369-75. } \\
\text { https://doi.org/10.1002/1097-0142(19930815)72:4<1369::AID-CNCR2820720436>3.0.CO;2-L. }\end{array}$ & 281 & 10.41 \\
\hline 17 & $\begin{array}{l}\text { La Vecchia C, Tavani A, Franceschi S, Levi F, Corrao G, Negri E. Epidemiology and prevention of oral cancer. } \\
\text { Oral Oncology. 1997;33(5):302-12. }\end{array}$ & 278 & 12.09 \\
\hline 18 & $\begin{array}{l}\text { Syrianen S. Human papillomavirus (HPV) in head and neck cancer. Journal of Clinical Virology. } \\
\text { 2005;32:S59-S66. https://doi.org/10.1016/i.jcv.2004.11.017. }\end{array}$ & 275 & 18.33 \\
\hline 19 & $\begin{array}{c}\text { Graham S, Dayal H, Rohrer T, Swanson M, Sultz H, Shedd D, et al. Dentition, diet, tobacco, and } \\
\text { alcohol in epidemiology of oral cancer. Journal of the National Cancer Institute. 1977;59(6):161 1-8. } \\
\text { https://doi.org/10.1093/inci/59.6.1611. }\end{array}$ & 264 & 6.14 \\
\hline
\end{tabular}




\begin{tabular}{|c|c|c|c|}
\hline Rank & Reference & Citations & $\begin{array}{l}\text { Citation } \\
\text { density* }\end{array}$ \\
\hline 20 & $\begin{array}{c}\text { Franco EL, Kowalski LP, Oliveira BV, Curado MP, Pereira RN, Silva ME, et al. Risk-factors for } \\
\text { oral-cancer in Brazil - a case-control study. International Journal of Cancer. 1989;43(6):992-1000. } \\
\text { https://doi.org/10.1002/ijc.2910430607. }\end{array}$ & 258 & 8.32 \\
\hline 21 & $\begin{array}{c}\text { Jeng JH, Chang MC, Hahn LJ. Role of areca nut in betel quid-associated chemical } \\
\text { carcinogenesis: current awareness and future perspectives. Oral Oncology. 2001;37(6):477-92. } \\
\text { https://doi.org/10.1016/S1368-8375(01)00003-3. }\end{array}$ & 257 & 13.53 \\
\hline 22 & $\begin{array}{l}\text { Nair U, Bartsch H, Nair J. Alert for an epidemic of oral cancer due to use of the betel quid substitutes } \\
\text { gutkha and pan masala: a review of agents and causative mechanisms. Mutagenesis. 2004;19(4):251-62. } \\
\text { https://doi.org/10.1093/mutage/geh036. }\end{array}$ & 247 & 15.44 \\
\hline 23 & $\begin{array}{c}\text { Gupta PC, Ray CS. Smokeless tobacco and health in India and South Asia. Respirology. 2003;8(4):419-31. } \\
\text { https://doi.org/10.1046/j.1440-1843.2003.00507.x. }\end{array}$ & 244 & 14.35 \\
\hline 24 & $\begin{array}{l}\text { Scully C, Bagan J. Oral squamous cell carcinoma overview. Oral Oncology. 2009;45(4-5):301-8. } \\
\text { hittps://doi.org/10.1016/i.oraloncology.2009.01.004. }\end{array}$ & 242 & 22.00 \\
\hline 25 & $\begin{array}{c}\text { Ragin CCR, Modugno F, Gollin SM. The epidemiology and risk factors of head and neck } \\
\text { cancer: a focus on human papillomavirus. Journal of Dental Research. 2007;86(2):104-14. } \\
\text { https://doi.org/10.1177/154405910708600202. }\end{array}$ & 235 & 18.08 \\
\hline 26 & $\begin{array}{r}\text { Hobbs CGL, Sterne JAC, Bailey M, Heyderman RS, Birchall MA, Thomas SJ. Human papillomavirus and } \\
\text { head and neck cancer: a systematic review and meta-analysis. Clinical Otolaryngology. 2006;31 (4):259-66. } \\
\text { https://doi.org/10.1111/j.1749-4486.2006.01246.x. }\end{array}$ & 232 & 16.57 \\
\hline 27 & $\begin{array}{c}\text { Vigneswaran N, Williams MD. Epidemiologic trends in head and neck cancer and AIDS in } \\
\text { diagnosis. Oral and Maxillofacial Surgery Clinics of North America. 2014;26(2):123-41. } \\
\text { https://doi.org/10.1016/i.coms.2014.01.001. }\end{array}$ & 227 & 37.83 \\
\hline 28 & Kademani D. Oral cancer. Mayo Clinic Proceedings. 2007;82(7):878-87. https://doi.org/10.4065/82.7.878. & 214 & 16.46 \\
\hline 29 & $\begin{array}{l}\text { Chen YJ, Chang JTC, Liao CT, Wang HM, Yen TC, Chiu CC, et al. Head and neck cancer in the betel } \\
\text { quid chewing area: recent advances in molecular carcinogenesis. Cancer Science. 2008;99(8):1507-14. } \\
\text { https://doi.org/10.1111/j.1349-7006.2008.00863.x. }\end{array}$ & 209 & 17.42 \\
\hline 30 & $\begin{array}{l}\text { Znaor A, Brennan P, Gajalakshmi V, Mathew A, Shanta V, Varghese C, et al. Independent and combined effects } \\
\text { of tobacco smoking, chewing and alcohol drinking on the risk of oral, pharyngeal and esophageal cancers in } \\
\text { indian men. International Journal of Cancer. 2003;105(5):681-6. https://doi.org/10.1002/ijc. } 11114 \text {. }\end{array}$ & 206 & 12.12 \\
\hline 31 & $\begin{array}{l}\text { Critchley JA, Unal B. Health effects associated with smokeless tobacco: a systematic review. Thorax. } \\
\qquad 2003 ; 58(5): 435-43 \text {. https://doi.org/10.1136/thorax.58.5.435. }\end{array}$ & 202 & 11.88 \\
\hline 32 & $\begin{array}{l}\text { Heck JE, Berthiller J, Vaccarella S, Winn DM, Smith E, Shangina O, et al. Sexual behaviours and the risk of head } \\
\text { and neck cancers: a pooled analysis in the International Head and Neck Cancer Epidemiology (INHANCE) } \\
\text { consortium. International Journal of Epidemiology. 2010;39(1):166-81. https://doi.org/10.1093/ije/dyp350. }\end{array}$ & 201 & 20.10 \\
\hline 33 & $\begin{array}{l}\text { Homann N, Tillonen J, Meurman JH, Rintamaki H, Lindqvist C, Rautio M, et al. Increased salivary acetaldehyde } \\
\text { levels in heavy drinkers and smokers: a microbiological approach to oral cavity cancer. Carcinogenesis. } \\
\qquad 2000 ; 21(4): 663-8 \text {. https://doi.org/10.1093/carcin/21.4.663. }\end{array}$ & 199 & 9.95 \\
\hline 34 & $\begin{array}{l}\text { Pavia M, Pileggi C, Nobile CGA, Angelillo IF. Association between fruit and vegetable consumption and oral } \\
\text { cancer: a meta-analysis of observational studies. American Journal of Clinical Nutrition. 2006;83(5):1 126-34. }\end{array}$ & 195 & 13.93 \\
\hline 35 & $\begin{array}{c}\text { Scully C, Field JK, Tanzawa H. Genetic aberrations in oral or head and neck squamous cell carcinoma } \\
\text { (SCCHN): 1. carcinogen metabolism, dna repair and cell cycle control. Oral Oncology. 2000;36(3):256-63. } \\
\text { https://doi.org/10.1016/S1368-8375(00)00007-5. }\end{array}$ & 187 & 9.35 \\
\hline 36 & $\begin{array}{l}\text { Chung FL, Schwartz J, Herzog CR, Yang YM. Tea and cancer prevention: studies in animals and humans. Journal } \\
\text { of Nutrition. 2003;133(10):3268S-74S. }\end{array}$ & 186 & 10.94 \\
\hline 37 & $\begin{array}{l}\text { Kreimer AR, Johansson M, Waterboer T, Kaaks R, Chang-Claude J, Drogen D, et al. Evaluation of human } \\
\text { papillomavirus antibodies and risk of subsequent head and neck cancer. Journal of Clinical Oncology. } \\
\qquad 2013 ; 31(21): 2708-15 \text {. https://doi.org/10.1200/JCO.2012.47.2738. }\end{array}$ & 185 & 26.43 \\
\hline 38 & $\begin{array}{l}\text { Balaram P, Sridhar H, Rajkumar T, Vaccarella S, Herrero R, Nandakumar A, et al. Oral cancer in southern } \\
\text { india: the influence of smoking, drinking, paan-chewing and oral hygiene. International Journal of Cancer. } \\
\qquad 2002 ; 98(3): 440-5 \text {. https://doi.org/10.1002/ijc. } 10200 .\end{array}$ & 184 & 10.22 \\
\hline 39 & Rivera C. Essentials of oral cancer. International Journal of Clinical and Experimental Pathology. 2015;8(9):1 1884-94. & 183 & 36.60 \\
\hline 40 & $\begin{array}{c}\text { Rao SVK, Mejia G, Roberts-Thomson K, Logan R. Epidemiology of oral cancer in Asia in the past } \\
\text { decade- an update (2000-2012). Asian Pacific Journal of Cancer Prevention. 2013;14(10):5567-77. } \\
\text { https://doi.org/10.7314/APJCP.2013.14.10.5567. }\end{array}$ & 181 & 25.86 \\
\hline
\end{tabular}




\begin{tabular}{|c|c|c|c|}
\hline Rank & Reference & Citations & $\begin{array}{l}\text { Citation } \\
\text { density* }\end{array}$ \\
\hline 41 & $\begin{array}{c}\text { Syrianen S, Lodi G, von Bultzingslowen I, Aliko A, Arduino P, Campisi G, et al. Human papillomaviruses in } \\
\text { oral carcinoma and oral potentially malignant disorders: a systematic review. Oral Diseases. } 2011 \text {; 17:58-72. } \\
\text { https://doi.org/10.1111/j.1601-0825.2011.01792.x. }\end{array}$ & 179 & 19.89 \\
\hline 42 & $\begin{array}{l}\text { Petti S, Scully C. Polyphenols, oral health and disease: a review. Journal of Dentistry. 2009;37(6):413-23. } \\
\text { https://doi.org/10.1016/j.jdent.2009.02.003. }\end{array}$ & 179 & 16.27 \\
\hline 43 & $\begin{array}{l}\text { Warnakulasuriya S, Dietrich T, Bornstein MM, Peidro EC, Preshaw PM, Walter C, et al. Oral health } \\
\text { risks of tobacco use and effects of cessation. International Dental Journal. 2010;60(1):7-30. } \\
\text { https://doi.org/10.1922/IDJ_2532Warnakulasuriya24. }\end{array}$ & 177 & 17.70 \\
\hline 44 & $\begin{array}{l}\text { Conway DI, Petticrew M, Marlborough H, Bertbiller J, Hashibe M, Macpherson LMD. Socioeconomic inequalities } \\
\text { and oral cancer risk: a systematic review and meta-analysis of case-control studies. International Journal of } \\
\text { Cancer. 2008;122(12):281 1-9. https://doi.org/10.1002/iic.23430. }\end{array}$ & 176 & 14.67 \\
\hline 45 & $\begin{array}{l}\text { Vainio H, Weiderpass E. Fruit and vegetables in cancer prevention. Nutrition and Cancer. 2006;54(1):11 1-42. } \\
\text { https://doi.org/10.1207/s15327914nc5401_13. }\end{array}$ & 176 & 12.57 \\
\hline 46 & $\begin{array}{l}\text { Warnakulasuriya S. Living with oral cancer: epidemiology with particular reference to } \\
\text { prevalence and life-style changes that influence survival. Oral Oncology. 2010;46(6):407-10. } \\
\text { https://doi.org/10.1016/j.oraloncology.2010.02.015. }\end{array}$ & 170 & 17.00 \\
\hline 47 & $\begin{array}{l}\text { Day GL, Blot WJ. 2nd primary tumors in patients with oral-cancer. Cancer. 1992;70(1):14-9. } \\
\text { https://doi.org/10.1002/1097-0142(19920701)70:1 <14::AID-CNCR2820700103>3.0.CO;2-S. }\end{array}$ & 167 & 5.96 \\
\hline 48 & $\begin{array}{l}\text { Petti S. Lifestyle risk factors for oral cancer. Oral Oncology. 2009;45(4-5):340-50. } \\
\text { https://doi.org/10.1016/i.oraloncology.2008.05.018. }\end{array}$ & 166 & 15.09 \\
\hline 49 & $\begin{array}{l}\text { Meyer MS, Joshipura K, Giovannucci E, Michaud DS. A review of the relationship between tooth loss, periodontal } \\
\text { disease, and cancer. Cancer Causes \& Control. 2008;19(9):895-907. https://doi.org/10.1007/s1 0552-008-9163-4. }\end{array}$ & 164 & 13.67 \\
\hline 50 & $\begin{array}{l}\text { Moore C. Cigarette smoking and cancer of mouth, pharynx, and larynx - continuing study. Journal of the } \\
\text { American Medical Association. } 1971 ; 218(4): 553-8 \text {. https://doi.org/10.1001/jama.218.4.553. }\end{array}$ & 164 & 3.35 \\
\hline 51 & $\begin{array}{l}\text { Gillison ML. Current topics in the epidemiology of oral cavity and oropharyngeal cancers. Head and Neck. } \\
\qquad 2007 ; 29(8): 779-92 \text {. https://doi.org/10.1002/hed.20573. }\end{array}$ & 162 & 12.46 \\
\hline 52 & $\begin{array}{c}\text { Castellsague X, Quintana MJ, Martinez MC, Nieto A, Sanchez MJ, Juan A, et al. The role of type of tobacco } \\
\text { and type of alcoholic beverage in oral carcinogenesis. International Journal of Cancer. 2004;108(5):741-9. } \\
\text { https://doi.org/10.1002/ijc. } 11627 .\end{array}$ & 161 & 10.06 \\
\hline 53 & $\begin{array}{l}\text { Trivedy CR, Craig G, Warnakulasuriya S. The oral health consequences of chewing areca nut. Addiction Biology. } \\
\qquad 2002 ; 7(1): 115-25 \text {. https://doi.org/10.1080/13556210120091482. }\end{array}$ & 157 & 8.72 \\
\hline 54 & $\begin{array}{l}\text { Schildt EB, Eriksson M, Hardell L, Magnuson A. Oral snuff, smoking habits and alcohol consumption in } \\
\text { relation to oral cancer in a swedish case-control study. International Journal of Cancer. 1998;77(3):341 -6. } \\
\text { https://doi.org/ 10.1002/(SICI) 1097-0215(19980729)77:3<341::AID-IJC6>3.3.CO;2-Q. }\end{array}$ & 157 & 7.14 \\
\hline 55 & $\begin{array}{l}\text { Miller CS, White DK. Human papillomavirus expression in oral mucosa, premalignant conditions, and squamous } \\
\text { cell carcinoma - a retrospective review of the literature. Oral Surgery Oral Medicine Oral Pathology Oral } \\
\text { Radiology and Endodontology. 1996;82(1):57-68. https://doi.org/10.1016/S1079-2104(96)80378-7. }\end{array}$ & 157 & 6.54 \\
\hline 56 & $\begin{array}{c}\text { Llewellyn CD, Linklater K, Bell J, Johnson NW, Warnakulasuriya S. An analysis of risk factors } \\
\text { for oral cancer in young people: a case-control study. Oral Oncology. 2004;40(3):304-13. } \\
\text { https://doi.org/10.1016/i.oraloncology.2003.08.015. }\end{array}$ & 156 & 9.75 \\
\hline 57 & $\begin{array}{l}\text { Day GL, Blot WJ, Austin DF, Bernstein L, Greenberg RS, Prestonmartin S, et al. Racial-differences in risk of oral } \\
\text { and pharyngeal cancer - alcohol, tobacco, and other determinants. Journal of the National Cancer Institute. } \\
1993 ; 85(6): 465-73 \text {. https://doi.org/10.1093/inci/85.6.465. }\end{array}$ & 154 & 5.70 \\
\hline 58 & $\begin{array}{l}\text { Levi F, Pasche C, La Vecchia C, Lucchini F, Franceschi S, Monnier P. Food groups and } \\
\text { risk of oral and pharyngeal cancer. International Journal of Cancer. 1998;77(5):705-9. } \\
\text { https://doi.org/10.1002/(SICI) 1097-0215(19980831)77:5<705::AID-IJC8>3.3.CO;2-Z. }\end{array}$ & 153 & 6.95 \\
\hline 59 & $\begin{array}{l}\text { Geisler SA, Olshan AF. GSTM1, GSTT1, and the risk of squamous cell carcinoma of the head and neck: a mini-HuGE } \\
\text { review. American Journal of Epidemiology. 2001;154(2):95-105. https://doi.org/10.1093/aje/154.2.95. }\end{array}$ & 151 & 7.95 \\
\hline 60 & $\begin{array}{l}\text { Luo J, Ye W, Zendehdel K, Adami J, Adami HO, Boffetta P, et al. Oral use of swedish moist snuff (snus) and risk } \\
\text { for cancer of the mouth, lung, and pancreas in male construction workers: a retrospective cohort study. Lancet. } \\
\qquad 2007 ; 369(9578): 2015-20 \text {. https://doi.org/10.1016/S0140-6736(07)60678-3. }\end{array}$ & 150 & 11.54 \\
\hline 61 & $\begin{array}{c}\text { Hung HC, Chuang J, Chien YC, Chern HD, Chiang CP, Kuo YS, et al. Genetic polymorphisms of CYP2E 1, } \\
\text { GSTM1, and GSTT1; environmental factors and risk of oral cancer. Cancer Epidemiology Biomarkers \& } \\
\text { Prevention. 1997;6(1 1):901-5. }\end{array}$ & 150 & 6.52 \\
\hline
\end{tabular}




\begin{tabular}{|c|c|c|c|}
\hline Rank & Reference & Citations & $\begin{array}{l}\text { Citation } \\
\text { density* }\end{array}$ \\
\hline 62 & $\begin{array}{c}\text { Jin LJ, Lamster IB, Greenspan JS, Pitts NB, Scully C, Warnakulasuriya S. Global burden of oral diseases: } \\
\text { emerging concepts, management and interplay with systemic health. Oral Diseases. 2016;22(7):609-19. } \\
\text { https://doi.org/10.1111/odi.12428. }\end{array}$ & 149 & 37.25 \\
\hline 63 & $\begin{array}{l}\text { Pelucchi C, Gallus S, Garavello W, Bosetti C, La Vecchia C. Alcohol and tobacco use, and cancer risk } \\
\text { for upper aerodiaestive tract and liver. European Journal of Cancer Prevention. 2008; 17(4):340-4. } \\
\text { https://doi.org/10.1097/CEJ.0b013e3282f75e91. }\end{array}$ & 146 & 12.17 \\
\hline 64 & $\begin{array}{l}\text { Smith E, Hoffman HT, Summersgill KS, Kirchner HL, Turek LP, Haugen TH. Human papillomavirus and risk of oral } \\
\text { cancer. Laryngoscope. 1998;108(7):1098-103. https://doi.org/10.1097/00005537-199807000-00027. }\end{array}$ & 144 & 6.55 \\
\hline 65 & $\begin{array}{l}\text { Sturgis EM, Wei QY, Spitz MR. Descriptive epidemiology and risk factors for head and neck cancer. Seminars In } \\
\text { Oncology. 2004;31(6):726-33. https://doi.org/10.1053/i.seminoncol.2004.09.013. }\end{array}$ & 141 & 8.81 \\
\hline 66 & $\begin{array}{l}\text { Keller A, Terris M. The association of alcohol and tobacco with cancer of the mouth and } \\
\text { pharynx. American Journal of Public Health and the Nations Health. 1965;55(10):1578-85. } \\
\text { https://doi.org/10.2105/AJPH.55.10.1578. }\end{array}$ & 140 & 2.55 \\
\hline 67 & $\begin{array}{l}\text { Scully C, Bagan J. Oral squamous cell carcinoma: overview of current understanding of aetiopathogenesis and } \\
\text { clinical implications. Oral Diseases. } 2009 ; 15(6): 388-99 \text {. https://doi.org/10.1111/j.1601-0825.2009.01563.x. }\end{array}$ & 137 & 12.45 \\
\hline 68 & $\begin{array}{l}\text { Pelucchi C, Gallus S, Garavello W, Bosetti C, La Vecchia C. Cancer risk associated with alcohol and tobacco } \\
\text { use: focus on upper aero-digestive tract and liver. Alcohol Research \& Health. 2006;29(3):193-8. }\end{array}$ & 137 & 9.79 \\
\hline 69 & $\begin{array}{l}\text { Palefsky JM. Human papillomavirus-related disease in men: not just a women's issue. Journal of Adolescent } \\
\text { Health. 2010;46(4):S12-S9. https://doi.org/10.1016/i.jadohealth.2010.01.010. }\end{array}$ & 135 & 13.50 \\
\hline 70 & $\begin{array}{l}\text { Rodu B, Jansson C. Smokeless tobacco and oral cancer: a review of the risks and determinants. Critical Reviews } \\
\text { In Oral Biology \& Medicine. } 2004 ; 15(5): 252-63 \text {. https://doi.org/10.1177/154411130401500502. }\end{array}$ & 134 & 8.38 \\
\hline 71 & $\begin{array}{c}\text { Rosenquist K, Wennerberg J, Schildt EB, Bladstrom A, Hansson BG, Andersson G. Oral status, oral } \\
\text { infections and some lifestyle factors as risk factors for oral and oropharyngeal squamous cell carcinoma: a } \\
\text { population-based case-control study in southern Sweden. Acta Oto-Laryngologica. 2005;125(12):1327-36. } \\
\text { https://doi.org/10.1080/00016480510012273. }\end{array}$ & 133 & 8.87 \\
\hline 72 & $\begin{array}{l}\text { Hashibe M, Morgenstern H, Cui Y, Tashkin DP, Zhang ZF, Cozen W, et al. Marijuana use and the risk of lung } \\
\text { and upper aerodigestive tract cancers: results of a population-based case-control study. Cancer Epidemiology } \\
\text { Biomarkers \& Prevention. 2006; } 15(10): 1829-34 \text {. https://doi.org/10.1 158/1055-9965.EPI-06-0330. }\end{array}$ & 132 & 9.43 \\
\hline 73 & $\begin{array}{l}\text { Bouda M, Gorgoulis VG, Kastrinakis NG, Giannoudis A, Tsoli E, Danassi-Afentaki D, et al. High risk HPV types } \\
\text { are frequently detected in potentially malignant and malignant oral lesions, but not in normal oral mucosa. } \\
\text { Modern Pathology. 2000;13(6):644-53. https://doi.org/10.1038/modpathol.3880113. }\end{array}$ & 131 & 6.55 \\
\hline 74 & $\begin{array}{c}\text { Park JY, Muscat J, Ren Q, Schantz SP, Harwick RD, Stern JC, et al. CYPIA1 and GSTM1 polymorphisms and oral } \\
\text { cancer risk. Cancer Epidemiology Biomarkers \& Prevention. 1997;6(10):791-7. }\end{array}$ & 131 & 5.70 \\
\hline 75 & $\begin{array}{l}\text { Petti S, Masood M, Scully C. The magnitude of tobacco smoking-betel quid chewing-alcohol drinking } \\
\text { interaction effect on oral cancer in south-east Asia. a meta-analysis of observational studies. PloS One. } \\
\qquad 2013 ; 8(11): \text { :e78999. https://doi.org/10.1371/journal.pone.0078999. }\end{array}$ & 130 & 18.57 \\
\hline 76 & $\begin{array}{l}\text { Winn DM, Blot WJ, Mclaughlin JK, Austin DF, Greenberg RS, Prestonmartin S, et al. Mouthwash use and oral } \\
\text { conditions in the risk of oral and pharyngeal cancer. Cancer Research. 1991;51 (1 1):3044-7. }\end{array}$ & 130 & 4.48 \\
\hline 77 & $\begin{array}{c}\text { Maden C, Beckmann AM, Thomas DB, Mcknight B, Sherman KJ, Ashley RL, et al. Human papillomaviruses, } \\
\text { herpes-simplex viruses, and the risk of oral-cancer in men. American Journal of Epidemiology. } \\
\text { 1992;135(10):1093-102. https://doi.org/10.1093/oxfordjournals.aje.a } 16209 .\end{array}$ & 127 & 4.54 \\
\hline 78 & $\begin{array}{l}\text { Lajer CB, Nielsen FC, Friis-Hansen L, Norrild B, Borup R, Garnaes E, et al. Different mirna signatures of } \\
\text { oral and pharyngeal squamous cell carcinomas: a prospective translational study. British Journal of Cancer. } \\
\qquad 2011 ; 104(5): 830-40 \text {. https://doi.org/10.1038/bic.2011.29. }\end{array}$ & 124 & 13.78 \\
\hline 79 & $\begin{array}{c}\text { Zheng TZ, Boyle P, Hu HF, Duan J, Jiang PJ, Ma DQ, et al. Dentition, oral hygiene, and risk of oral cancer: } \\
\text { a case-control study in Beiijing, People's Republic of China. Cancer Causes \& Control. 1990; (3):235-41. } \\
\text { https://doi.org/10.1007/BF001 17475. }\end{array}$ & 124 & 4.13 \\
\hline 80 & $\begin{array}{c}\text { Schmidt BL, Kuczynski J, Bhattacharya A, Huey B, Corby PM, Queiroz ELS, et al. Changes in } \\
\text { abundance of oral microbiota associated with oral cancer. PloS One. 2014;9(6):e106297. } \\
\text { https://doi.org/10.1371//ournal.pone.0098741. }\end{array}$ & 121 & 20.17 \\
\hline 81 & $\begin{array}{l}\text { Bundgaard T, Wildt J, Frydenberg M, Elbrond O, Nielsen JE. Case-control study of squamous-cell cancer of the } \\
\text { oral cavity in Denmark. Cancer Causes \& Control. 1995;6(1):57-67. https://doi.org/10.1007/BF00051681. }\end{array}$ & 121 & 4.84 \\
\hline 82 & $\begin{array}{l}\text { Freiman A, Bird G, Metelitsa Al, Barankin B, Lauzon GJ. Cutaneous effects of smoking. Journal of Cutaneous } \\
\text { Medicine and Surgery. 2004;8(6):415-23. https://doi.org/10.1007/s10227-005-0020-8. }\end{array}$ & 120 & 7.50 \\
\hline
\end{tabular}




\begin{tabular}{|c|c|c|c|}
\hline Rank & Reference & Citations & $\begin{array}{l}\text { Citation } \\
\text { density* }\end{array}$ \\
\hline 83 & $\begin{array}{c}\text { Merchant A, Husain SSM, Hosain M, Fikree FF, Pitiphat W, Siddiqui AR, et al. Paan without tobacco: } \\
\text { an independent risk factor for oral cancer. International Journal of Cancer. 2000;86(1):128-31. } \\
\text { https://doi.org/10.1002/(SICI) 1097-0215(20000401)86:1<128::AID-IJC20>3.0.CO;2-M. }\end{array}$ & 119 & 5.95 \\
\hline 84 & $\begin{array}{l}\text { Tsantoulis PK, Kastrinakis NG, Tourvas AD, Laskaris G, Gorgoulis VG. Advances in the biology of oral cancer. } \\
\text { Oral Oncology. 2007;43(6):523-34. https://doi.org/10.1016/i.oraloncology.2006.11.010. }\end{array}$ & 118 & 9.08 \\
\hline 85 & $\begin{array}{l}\text { Ribeiro KB, Levi JE, Pawlita M, Koifman S, Matos E, Eluf-Neto J, et al. Low human papillomavirus prevalence } \\
\text { in head and neck cancer: results from two large case-control studies in high-incidence regions. International } \\
\text { Journal of Epidemiology. } 2011 ; 40(2): 489-502 \text {. https://doi.org/10.1093/ije/dyq249. }\end{array}$ & 116 & 12.89 \\
\hline 86 & $\begin{array}{l}\text { Warnakulasuriya S, Sutherland G, Scully C. Tobacco, oral cancer, and treatment of dependence. Oral Oncology. } \\
\qquad 2005 ; 41(3): 244-60 \text {. https://doi.org/10.1016/i.oraloncology.2004.08.010. }\end{array}$ & 116 & 7.73 \\
\hline 87 & $\begin{array}{l}\text { Marron M, Boffetta P, Zhang ZF, Zaridze D, Wunsch V, Winn DM, et al. Cessation of alcohol drinking, } \\
\text { tobacco smoking and the reversal of head and neck cancer risk. International Journal of Epidemiology. } \\
\text { 2010;39(1):182-96. https://doi.org/10.1093/ije/dyp291. }\end{array}$ & 114 & 11.40 \\
\hline 88 & $\begin{array}{l}\text { Hashibe M, Straif K, Tashkin DP, Morgenstern H, Greenland S, Zhang ZF. Epidemiologic review of marijuana use } \\
\text { and cancer risk. Alcohol. 2005;35(3):265-75. https://doi.org/10.1016/i.alcohol.2005.04.008. }\end{array}$ & 113 & 7.53 \\
\hline 89 & $\begin{array}{l}\text { Boehm K, Borrelli F, Ernst E, Habacher G, Hung SK, Milazzo S, et al. Green tea (camellia sinensis) } \\
\text { for the prevention of cancer. Cochrane Database of Systematic Reviews. 2009;Blank(3):CD005004. } \\
\text { https://doi.org/10.1002/14651858.CD005004.pub2. }\end{array}$ & 112 & 10.18 \\
\hline 90 & $\begin{array}{c}\text { Sreelekha TT, Ramadas K, Pandey M, Thomas G, Nalinakumari KR, Pillai MR. Genetic polymorphism } \\
\text { of CYP1A1, GSTM1 and GSTT1 genes in Indian oral cancer. Oral Oncology. 2001;37(7):593-8. } \\
\text { https://doi.org/10.1016/S1368-8375(01)00028-8. }\end{array}$ & 112 & 5.89 \\
\hline 91 & $\begin{array}{l}\text { Muwonge R, Ramadas K, Sankila R, Thara S, Thomas G, Vinoda J, et al. Role of tobacco smoking, chewing } \\
\text { and alcohol drinking in the risk of oral cancer in Trivandrum, India: a nested case-control design using incident } \\
\text { cancer cases. Oral Oncology. 2008;44(5):446-54. https://doi.org/10.1016/i.oraloncology.2007.06.002. }\end{array}$ & 111 & 9.25 \\
\hline 92 & $\begin{array}{l}\text { Hatsukami DK, Lemmonds C, Tomar SL. Smokeless tobacco use: harm reduction or induction approach? } \\
\text { Preventive Medicine. 2004;38(3):309-17. https://doi.org/10.1016/i.ypmed.2003.10.006. }\end{array}$ & 111 & 6.94 \\
\hline 93 & $\begin{array}{l}\text { Lissowska J, Pilarska A, Pilarski P, Samolczyk-Wanyura D, Piekarczyk J, Bardin-Mikolajczak A, et al. Smoking, } \\
\text { alcohol, diet, dentition and sexual practices in the epidemiology of oral cancer in Poland. European Journal of } \\
\text { Cancer Prevention. 2003;12(1):25-33. https://doi.org/10.1097/00008469-200302000-00005. }\end{array}$ & 111 & 6.53 \\
\hline 94 & $\begin{array}{l}\text { Katoh T, Kaneko S, Kohshi K, Munaka M, Kitagawa K, Kunugita N, et al. Genetic polymorphisms of } \\
\text { tobacco- and alcohol-related metabolizing enzymes and oral cavity cancer. International Journal of Cancer. } \\
\text { 1999;83(5):606-9. https://doi.org/10.1002/(SICI) 1097-0215(19991 126)83:5<606::AID-IJC6>3.0.CO;2-P. }\end{array}$ & 110 & 5.24 \\
\hline 95 & $\begin{array}{l}\text { Llewellyn CD, Johnson NW, Warnakulasuriya S. Risk factors for oral cancer in newly diagnosed patients aged } \\
45 \text { years and younger: a case-control study in southern England. Journal of Oral Pathology \& Medicine. } \\
\qquad 2004 ; 33(9): 525-32 \text {. https://doi.org/10.1 1 11/i.1600-0714.2004.00222.x. }\end{array}$ & 109 & 6.81 \\
\hline 96 & $\begin{array}{l}\text { Hayes RB, Bravo-Otero E, Kleinman DV, Brown LM, Fraumeni JF, Harty LC, et al. Tobacco and } \\
\text { alcohol use and oral cancer in Puerto Rico. Cancer Causes \& Control. 1999;10(1):27-33. } \\
\text { https://doi.org/10.1023/A:10088761 } 15797 .\end{array}$ & 109 & 5.19 \\
\hline 97 & $\begin{array}{l}\text { Mills CA, Porter MM. Tobacco smoking habits and cancer of the mouth and respiratory system. Cancer Research. } \\
\qquad 1950 ; 10(9): 539-42 .\end{array}$ & 109 & 1.56 \\
\hline 98 & $\begin{array}{l}\text { Waziry R, Jawad M, Ballout RA, Al Akel M, AkI EA. The effects of waterpipe tobacco smoking on health } \\
\text { outcomes: an updated systematic review and meta-analysis. International Journal of Epidemiology. } \\
\qquad 2017 ; 46(1): 32-43 \text {. https://doi.org/10.1093/ije/dyw021. }\end{array}$ & 108 & 36.00 \\
\hline 99 & $\begin{array}{l}\text { Warnakulasuriya S. Causes of oral cancer - an appraisal of controversies. British Dental Journal. } \\
\qquad 2009 ; 207(10): 471-5 . \text { https://doi.org/10.1038/sj.bdj.2009.1009. }\end{array}$ & 108 & 9.82 \\
\hline 100 & $\begin{array}{l}\text { Sato M, Sato T, Izumo T, Amagasa T. Genetic polymorphism of drug-metabolizing enzymes and susceptibility to } \\
\text { oral cancer. Carcinogenesis. 1999;20(10):1927-31. https://doi.org/10.1093/carcin/20.10.1927. }\end{array}$ & 108 & 5.14 \\
\hline
\end{tabular}

*Citation density $=$ mean number of citations per year.

accounted for less than $0.02 \%$ of the total WoS-CC citation count and were considered in this bibliometric analysis.

Considering different electronic databases, the total number of citations for the 15 most-cited articles was 8416 in WoS-CC, 9151 in Scopus, and 15458 in Google Scholar. Strong positive correlations were found between the number of citations in WoS-CC and Scopus ( $r=0.982 ; p<0.001)$, WoS-CC and Google 
Scholar ( $\mathrm{r}=0.939 ; \mathrm{p}<0.001)$, and Scopus and Google Scholar $(\mathrm{r}=0.957 ; \mathrm{p}<0.001)$.

A complete description of bibliometric indicators considering the study design is provided in Table 3. Case-control studies (articles, 39; citations, 8853) and narrative reviews (articles, 29; citations, 7486) accounted for more than half of the most-cited articles and citations. However, systematized reviews, cohort, and cross-sectional studies presented higher citation densities, indicating that these study designs were proportionally more cited considering years since publication.

A global map containing the number of articles and total citations per continent and country is shown in Figure 1. Considering the number of articles and total citations per continent, Europe (articles, 48; citations, 11285) and North America (articles, 36; citations, 7273) accounted for the majority of articles and citations, followed by Asia (articles, 7; citations, 1637) and South America (articles, 2; citations, 441). The remaining continents were represented by one country each-Central America by Costa Rica (articles, 1 ; citations, 837) and Oceania by Australia (articles, 1; citations, 181). At the country level, most articles were conducted in the US (articles, 35; citations, 7153), followed by the United Kingdom (articles, 16; citations, 4608) and France (articles, 9; citations, 2385). Among the 100 most-cited articles, only one article was from Brazil (citations, 258), and the authors were affiliated with the Ludwig Institute for Cancer Research.

VOSviewer maps representing the relationship between risk factors (as depicted by the authors of this study) and keywords used by the authors of the included articles are shown in Figure 2. Concerning risk factors, a large cluster was found concerning alcohol intake, smoked/smokeless tobacco, dietary factors, and HPV, with most articles on these topics published around 2000. Other factors, such as areca nut, betel leaf, and family history, were assessed in articles published around 2010. Similarly, classic keywords, such as alcohol and tobacco, were grouped in the same clusters and assessed by articles in the first decade of the 2000s. However, keyword heterogeneity might have introduced some degree of imprecision in cluster grouping.

Furthermore, VOSviewer maps representing the link between authors and countries are shown in Figure 3. The main author cluster was composed of prominent authors, such as Franceschi, Castellsagué, and Boffetta, in most articles published around 2010. Another large cluster was composed of authors such as Blot and Austin, although articles published by these authors were mostly published before 2000 . Moreover, country maps presented five large clusters, with a strong link between countries with a high number of published articles, such as the US, the United Kingdom, and France.

The included articles were published between 1950 and 2017 (Figure 4), with the most published in the first decade of the 2000s $(n=62)$ and with peaks of publications in $2004(n=8)$ and $2009(n=8)$. The oldest paper was a case-control study authored by Mills and Porter (1950), ${ }_{1}^{16}$ while the most recent paper was a systematic review authored by Waziry et al. ${ }^{17}$ The article with more citations was a narrative review

Table 3. Bibliometric indicators per study design of the 100 most-cited articles concerning intraoral squamous cell carcinoma and its associated factors.

\begin{tabular}{lccccc}
\hline Study design & Articles & Citations (WoS-CC) & Citation ratio $^{a}$ & Years of publication $^{b}$ & Citation density $^{c}$ \\
\hline Case-control study & 39 & 8,583 & 220.08 & 979 & 0.22 \\
Narrative review & 29 & 7,486 & 258.14 & 416 & 0.62 \\
Systematic review & 14 & 2,338 & 167.00 & 197 & 0.85 \\
Systematized review & 10 & 2,062 & 206.20 & 153 & 1.35 \\
Cohort study & 5 & 1,302 & 260.40 & 108 & 3.41 \\
Cross-sectional study & 3 & 444 & 148.00 & 38 & 3.89 \\
Total & 100 & 22,215 & 222.15 & 1,891 & 0.12 \\
\hline
\end{tabular}

WoS-CC: Web of Science Core Collection; ${ }^{a}$ Citation ratio: number of citations per number of articles in each study design; ${ }^{b}$ Years of publication: sum of years since publication in each study design; 'C Citation density: citation ratio per sum of years since publication in each study design. 


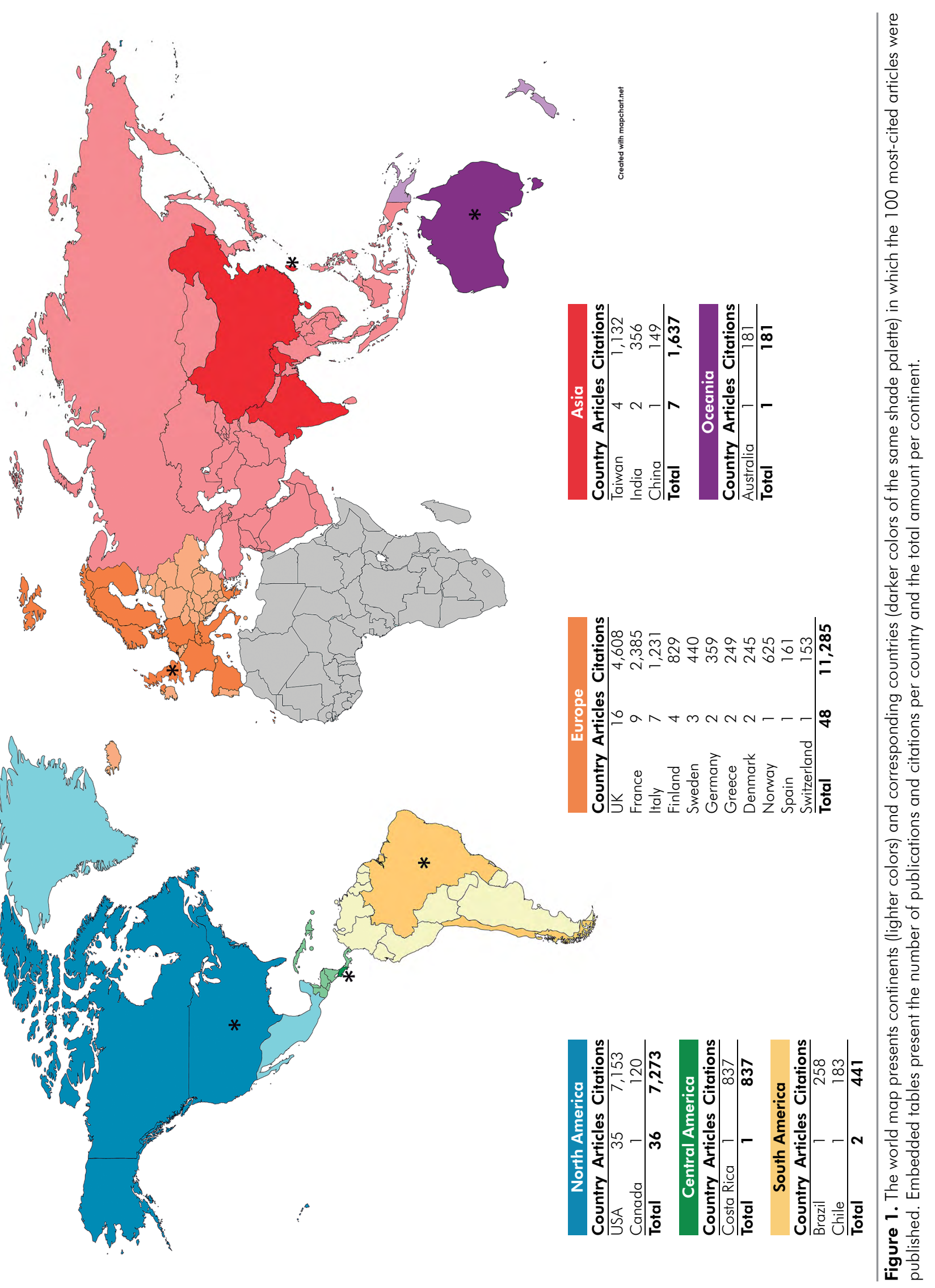



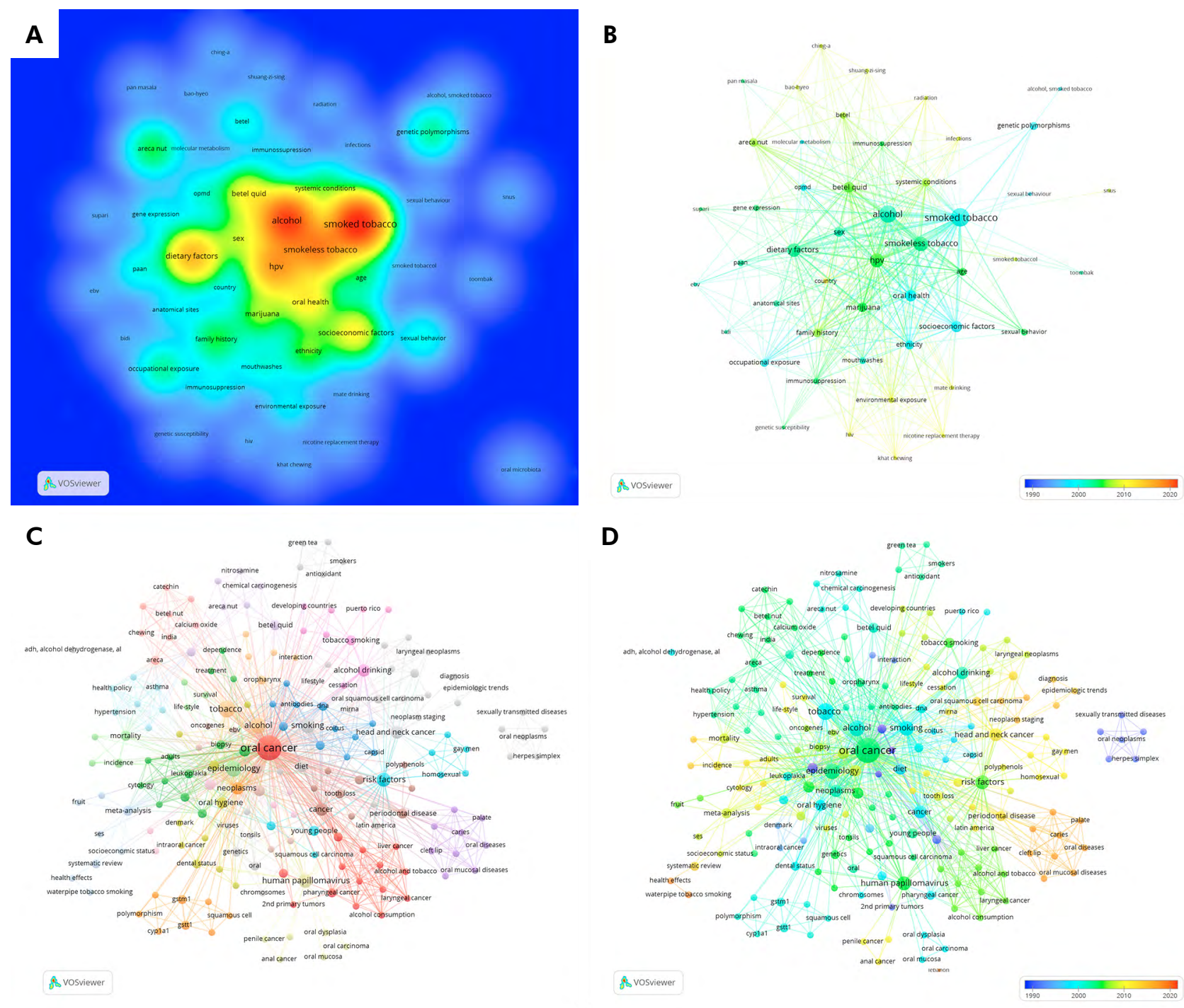

Figure 2. Co-occurrence maps. The authors' keywords from included studies and risk factors assigned by the bibliometric review authors are used as units of analysis, which are linked based on the number of common terms across articles. a) Density map in which risk factors are ranked based on number of occurrences across papers. b) Network map in which nodes and clusters of risk factors are colored based on publication year. c) Network map in which nodes and clusters of authors' keywords are colored based on number of co-occurrences across papers. d) Network map in which nodes and clusters of authors' keywords are colored based on publication year.

authored by Warnakulasuriya (citations, 1513; citation density, 137.55), published in 2009 in Oral Oncology. ${ }^{18}$

The top 15 authors with a higher number of articles in WoS-CC are listed in Table 4. The number of articles per top author ranged from five to 10, and the number of citations ranged from 1591 to 3171. The most prominent author in this context was S. Franceschi (articles, 10; citations, 3171), followed by Warnakulasuriya (articles, 10; citations, 2945) and Boffetta (articles, 9; citations, 2537).
Regarding research institutions (Table 5), the most prominent research institutions were the International Agency for Research on Cancer, France (articles, 10; citations, 2699); King's College London, England (articles, 9; citations, 2796); and National Cancer Institute, US (articles, 4; citations, 925). Most studies ( $n=61$ ) were conducted at universities, 39 studies were conducted at independent research institutes. Moreover, the corresponding author could not be identified in three studies. ${ }^{16,19,20}$ Furthermore, the 

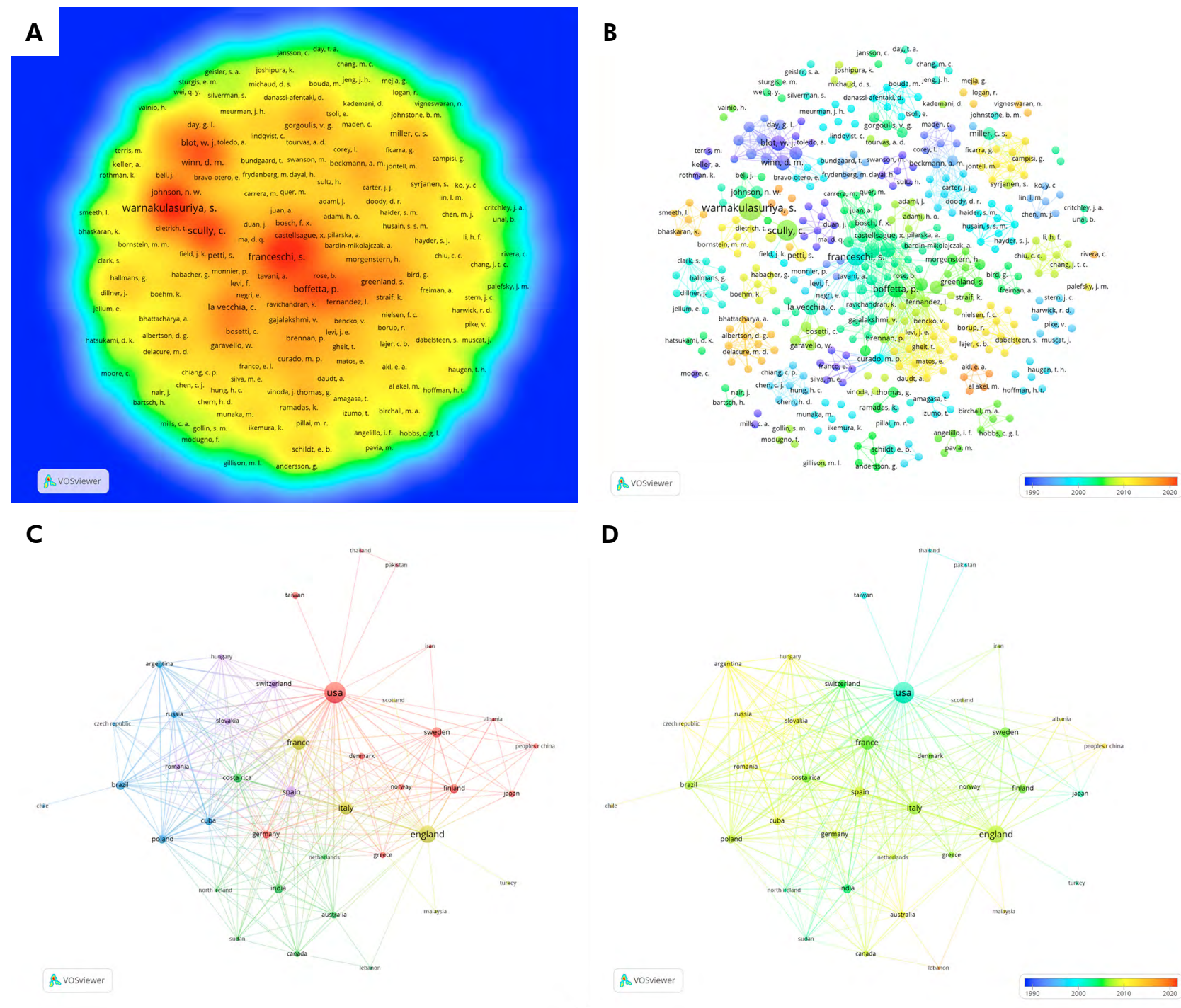

Figure 3. Co-authorship maps. The authors' names and countries are used as units of analysis, which are linked based on the number of jointly authored papers. a) Density map in which authors are ranked based on number of co-authored papers. b) Network map in which nodes and clusters of co-authors are colored based on publication year. c) Network map in which nodes and clusters of countries are colored based on number of co-authored papers. d) Network map in which nodes and clusters of countries are colored based on publication year.

open-access model was available in 29 and 25 studies published by universities and independent research institutes, respectively.

With regard to scientific journals (Table 6), the most common journal of most articles and citations was Oral Oncology (articles, 13; citations, 3716), followed by International Journal of Cancer (articles, 9; citations, 1524), Journal of the National Cancer Institute (articles, 5; citations, 2241); Cancer Epidemiology Biomarkers \& Prevention (articles, 4; citations, 969), and International Journal of Epidemiology (articles, 4; citations, 539).

\section{Discussion}

Bibliometric data are useful in identifying research trends and analyzing the potential of highly cited studies to influence the scientific and clinical community. Concerning oral cancer, two general bibliometric analyses have been published. ${ }^{21,} 22$ The analysis published by Penal-Cristobal et al. ${ }^{22}$ focused on general metrics. This study identified 41 studies assessing oral cancer etiology, although it only mentioned alcohol 

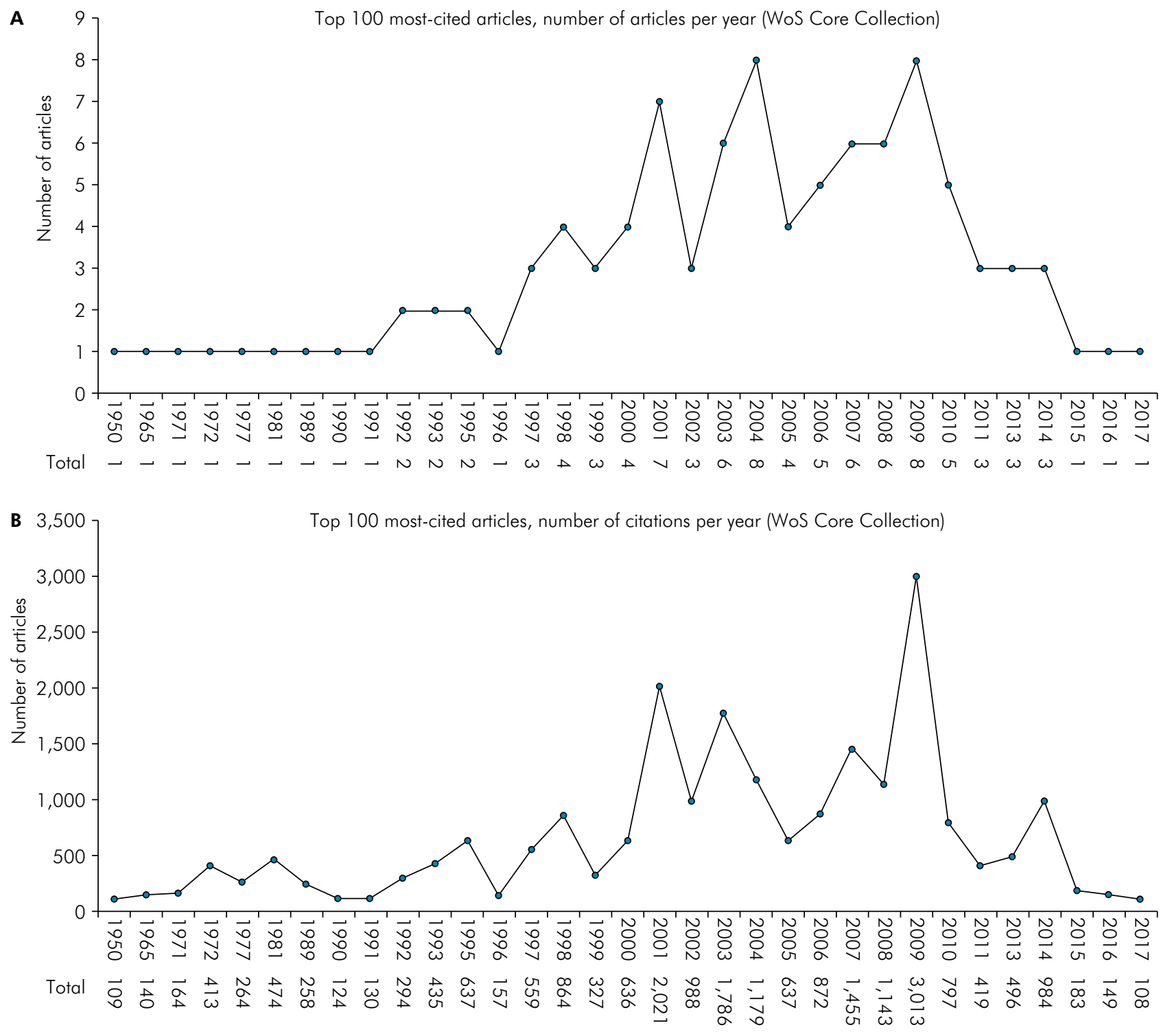

Figure 4. Line graph of the 100 most-cited articles: number of articles (a) and citations (b) per year in Web of Science Core Collection.

intake, tobacco smoking, and HPV infection as the main risk factors. According to Hassona et al., ${ }^{21}$ a total of 37 studies assessing the etiology of cancer of the mouth, lips, and oropharynx were reported. This bibliometric analysis further described the number of studies that assessed each risk factor.

Since the etiology of oral cancer is complex and multifactorial, ${ }^{1,7}$ the present bibliometric study aimed to focus solely on risk factors for intraoral SCC (i.e., excluding the lips, oropharynx, and pharynx), with the aim of minimizing heterogeneity. In the present bibliometric analysis, all risk factors assessed in each included article were manually extracted by the authors, which enabled an in-depth analysis through bibliometric maps. The maps generated were useful in identifying groups of highly active authors and countries and evaluating the academic interest in each risk factor over time.

The most prominent risk factors for intraoral SCC were tobacco smoking, alcohol consumption, smokeless tobacco consumption, HPV infection, and dietary factors. Alcohol and tobacco are considered major contributors to oral cancer due to their widespread consumption and synergistic effect, ${ }^{4,23}$ 
Table 4. Top 15 authors among the 100 most-cited articles concerning intraoral squamous cell carcinoma and its associated factors. Authors are ranked based on the number of authored or co-authored articles and citations in Web of Science Core Collection.

\begin{tabular}{lcccc}
\hline Rank & Author & Affiliation & Articles & Citations \\
\hline 1 & Franceschi S. & International Agency for Research on Cancer & 10 & 3,171 \\
2 & Warnakulasuriya S. & King's College London & 10 & 2,945 \\
3 & Boffetta P. & International Agency for Research on Cancer & 9 & 2,537 \\
4 & Herrero R. & Costa Rican Foundation for Training in Health Sciences & 8 & 2,740 \\
5 & Winn D. M. & National Cancer Institute & 8 & 2,314 \\
6 & Scully C. & University College London & 8 & 1,264 \\
7 & La Vecchia C. & Mario Negri Institute for Pharmacological Research & 7 & 1,960 \\
8 & Brennan P. & International Agency for Research on Cancer & 7 & 1,954 \\
9 & Hashibe M. & International Agency for Research on Cancer & 7 & 1,868 \\
10 & Castellsague X. & L'Hospitalet de Llobregat & 6 & 2,445 \\
11 & Curado M. P. & Hospital Araujo Jorge & 6 & 1,821 \\
12 & Schwartz S. M. & Fred Hutchinson Cancer Research Center & 5 & 1,857 \\
13 & Fernandez L. & Institute of Oncology and Radiobiology & 5 & 1,824 \\
14 & Levi F. & Centre Hospitalier Universitaire Vaudois & 5 & 1,677 \\
15 & Smith E. & University of lowa & 5 & 1,591 \\
\hline
\end{tabular}

Table 5. Top 15 Institutions among the 100 most-cited articles concerning intraoral squamous cell carcinoma and its associated factors. Institutions are ranked based on the number of articles and citations in Web of Science Core Collection.

\begin{tabular}{|c|c|c|c|c|}
\hline Rank & Institution & Country & Articles & Citations \\
\hline 1 & International Agency for Research on Cancer & France & 10 & 2,699 \\
\hline 2 & King's College London & England & 9 & 2,796 \\
\hline 3 & National Cancer Institute & USA & 4 & 925 \\
\hline 4 & Harvard University & USA & 3 & 696 \\
\hline 5 & University of California & USA & 3 & 639 \\
\hline 6 & University College London & England & 3 & 566 \\
\hline 7 & Sapienza Università di Roma & Italy & 3 & 475 \\
\hline 8 & Fred Hutchinson Cancer Research Center & USA & 2 & 537 \\
\hline 9 & University of Turku & Finland & 2 & 454 \\
\hline 10 & University of Kentucky & USA & 2 & 452 \\
\hline 11 & Mario Negri Institute for Pharmacological Research & Italy & 2 & 424 \\
\hline 12 & University of Texas & USA & 2 & 368 \\
\hline 13 & University of Athens & Greece & 2 & 249 \\
\hline 14 & Costa Rican Foundation for Training in Health Sciences & Costa Rica & 1 & 837 \\
\hline 15 & Medical University of South Carolina & USA & 1 & 734 \\
\hline
\end{tabular}

which is reflected by the high count of these terms. Although smokeless tobacco consumption is not as widespread as smoked tobacco consumption, there is an increasing number of studies assessing this habit, especially due to its relationship with the development of oral submucous fibrosis, which presents a high risk for malignancy. ${ }^{5}$ Moreover, although the number of highly cited studies on HPV infection highlights the scientific community interest on this topic, caution should be exercised since the current evidence is not consensual concerning its causal role in intraoral SCC. ${ }^{24}$ Further, papers assessing dietary factors were also relatively prominent, which often presented food groups with either protective effects, such as fruits and vegetables, ${ }^{25}$ or deleterious effects, such as processed meat, ${ }^{26}$ for intraoral SCC development.

Although less frequent, risk factors such as areca nut and betel quid must be emphasized. While areca 
nut may be an independent risk factor for intraoral SCC, it is used in the mixture of betel quid. ${ }^{8}$ Moreover, as recently highlighted by a bibliometric analysis focused on betel quid and oral cancer, most articles assessing this product were from China, Taiwan, and Hunan Province. ${ }^{27}$ This might also explain the lower number of articles assessing these factors among the top 100 most-cited included studies since most were from America and Europe, with only eight articles from Asian countries. This can be partially explained by the higher research budget and financial support provided by high-income countries compared to that provided by low- and middle-income countries. ${ }^{21}$

The most frequent study designs were case-control studies and narrative reviews. These studies provide background information about disease etiology, treatment, prognosis, and molecular mechanisms. At the bibliographic level, it is unclear whether the high number of citations is casual (i.e., generic citation on the subject in the introduction) or if these study designs influence the scientific argument of the cited study ${ }^{28}$ Since studies with lower levels of evidence often present high citation counts, this indicates that this metric does not necessarily correlate with study quality. ${ }^{29}$ For example, systematic reviews are considered studies with rigorous methods and high evidence level; nonetheless, narrative reviews accounted for almost twice as many articles and three times more citations. In this context, the two possible explanations for this phenomenon may be that narrative reviews may cover broader topics compared to systematic reviews (which are usually designed to answer a focused question) and that systematic reviews are actually a newer study design, with a relatively recent increase in popularity. ${ }^{30}$

Considering scientific journals, most were medical journals focused on oncology research. Among the top 15 journals, only four were dentistry-related ("Oral Oncology," "Oral Diseases," "Journal of Oral Pathology E Medicine," and "Oral Surgery Oral Medicine, Oral Pathology Oral Radiology and Endodontology"), highlighting the multidisciplinary aspect of oral cancer. Nonetheless, articles published in dental journals focused on the health conditions of the head and neck, while articles published in medical journals often presented a broader scope (i.e., assessing different types of cancers and anatomical locations), in which cancers of the oral cavity were also considered in the analysis.

Furthermore, universities accounted for $61 \%$ of published articles, but only $46 \%$ of the 15 most-cited articles. Although this metric does not necessarily reflect study quality, this finding could be partially explained by the "publish or perish" practice, which is related to the pressure to increase the number of publications. ${ }^{31}$ In addition, time availability might also have contributed to these findings since independent research institutes usually employ full-time researchers, in contrast to most university researchers that must perform other academic activities that often do not result in publications.

The time since publication was a concern due to its direct impact on the number of citations. Since older articles are more likely to accumulate citations, this can hinder the assessment of citation trends over time. It has been suggested that the true impact of a study can only be accurately assessed two decades after its publication, which might explain the prominent presence of articles published between the 1980s and 1990s in previous bibliometric analyses. ${ }^{32,33}$ To partially address this limitation, alternative metrics that account for the time since publication should be estimated, such as the citation density. Nonetheless, little variation in these metrics was found in this review because the majority of the top 10 most-cited articles were also present among the top 10 articles with the highest citation density.

Despite these concerns, it was observed that articles published in the first decade of the 2000s presented a higher number of publications and citations in the present review. This finding is in accordance with that of a recent bibliometric analyses of oral cancer. ${ }^{21,}$ ${ }^{22}$ A possible explanation for this phenomenon is that, in the early 2000s, articles began to be published in electronic format, facilitating information access and decoupling the likelihood of citation from the restrictions of printed research distribution. ${ }^{34}$

Although this bibliometric analysis did not focus on the analysis of sex disparities, it was observed that among the top 15 authors, only $40 \%$ were women. Nonetheless, there were 
approximately 500 individual authors in the present bibliometric analysis and this percentage might not be representative of the true proportion of female authors, which may be considerably lower. Previous studies have indicated that although there are no significant differences in scientific writing among men and women, ${ }^{35}$ women remain underrepresented concerning leadership positions and Hirsch index. ${ }^{36,37} \mathrm{~A}$ more in-depth analysis on this topic is recommended to further explore sex disparities in oncology research.

WoS-CC was defined as the reference database for analysis because of its recognition among the scientific community and the availability of robust tools for citation analysis. In this context, to provide an overview of the contribution of non-indexed research to the citation count, ${ }^{38}$ we also extracted total citations from Scopus and Google Scholar from the top 15 articles. While the number of citations from Scopus was only approximately $9 \%$ higher than that from WoS-CC, Google Scholar presented approximately $84 \%$ and $69 \%$ more citations than WoS-CC and Scopus, respectively. Although WoS-CC and Scopus do not include non-indexed sources of information, such as academic dissertations and theses, this type of research can significantly contribute to citation counts in Google Scholar.

Although no corrections concerning self-citations were performed in this review, they accounted for less than $0.02 \%$ of the total citations in WoS-CC, thus presenting a negligible contribution to the citation count. Moreover, self-citations and citations between colleagues from the same institutions may be considered misconduct when performed with the sole intention of increasing citations ${ }^{39}$ In counterpart, when authors belong to a research group and work in a series of experiments, self-citations are likely to appear as a way to clarify the research topic of the cited article. ${ }^{40}$

\section{Limitations}

Since WoS-CC was the reference database, articles published prior to starting the coverage date (1945) were not analyzed. Moreover, despite this bibliometric analysis using a comprehensive search strategy, some articles with restricted metadata availability in
WoS-CC might not have been identified. One example is the highly cited article published by Blot et al. (1988), ;1 although this study would otherwise meet the proposed eligibility criteria, it was not identified in the literature search. In particular, no abstract or keywords were available in WoS-CC, which severely hindered its discoverability. Therefore, this may impact the results of this bibliometric analysis, particularly considering older articles, which may have an increased chance of not being included due to poor discoverability.

Moreover, as most studies were conducted in the US and European countries, regional factors can be underestimated, such as the deleterious effect of Maté consumption in South America. ${ }^{42}$ Lastly, although bibliometric maps of risk factors were created to provide a more in-depth analysis, some degree of bias might have been introduced since this information was collected from primary studies and not directly exported from WoS-CC. Although agreed on before data extraction commenced, this may have impacted the results because of the authors' perceptions of which risk factors belong to each of the groups analyzed (e.g., environmental exposure and socioeconomic factors).

\section{Conclusions}

Alcohol intake, tobacco consumption, and HPV infection were the most studied risk factors for intraoral SCC development, although interest in other factors such as areca nut and betel quid has grown in recent decades. Narrative reviews and case-control studies were the most prominent study design. The country and institution with the highest number of articles and citations were the US and the International Agency for Research on Cancer, respectively. The data provided can guide future research and better inform healthcare providers regarding research trends and the impact of articles published in the field of oral cancer.

\section{Acknowledgments}

This study was supported in part by the Coordenação de Aperfeiçoamento de Pessoal de Nível Superior - Brasil (CAPES) - Finance Code 001. 


\section{References}

1. Montero PH, Patel SG. Cancer of the oral cavity. Surg Oncol Clin N Am. 2015 Jul;24(3):491-508. https://doi.org/10.1016/i.soc.2015.03.006

2. Jiang X, Wu J, Wang J, Huang R. Tobacco and oral squamous cell carcinoma: A review of carcinogenic pathways. Tob Induc Dis. 2019 Apr;17(1):29. https://doi.org/10.18332/tid/111652

3. Reidy J, McHugh E, Stassen LF. A review of the relationship between alcohol and oral cancer. Surgeon. 2011 Oct;9(5):278-83. https://doi.org/10.1016/i.surge.2011.01.010

4. Mello FW, Melo G, Pasetto JJ, Silva CA, Warnakulasuriya S, Rivero ER. The synergistic effect of tobacco and alcohol consumption on oral squamous cell carcinoma: a systematic review and meta-analysis. Clin Oral Investig. 2019 Jul;23(7):2849-59. https://doi.org/10.1007/s00784-019-02958-1

5. Warnakulasuriya S, Straif K. Carcinogenicity of smokeless tobacco: evidence from studies in humans \& experimental animals. Indian J Med Res. 2018 Dec;148(6):681-6. https://doi.org/10.4103/iimr.IJMR_149_18

6. Niaz K, Maqbool F, Khan F, Bahadar H, Ismail Hassan F, Abdollahi M. Smokeless tobacco (paan and gutkha) consumption, prevalence, and contribution to oral cancer. Epidemiol Health. 2017 Mar;39:e2017009. https://doi.org/10.4178/epih.e2017009

7. Chi AC, Day TA, Neville BW. Oral cavity and oropharyngeal squamous cell carcinoma-an update. CA Cancer J Clin. 2015 Sep-Oct;65(5):401-21. https://doi.org/10.3322/caac.21293

8. Trivedy CR, Craig G, Warnakulasuriya S. The oral health consequences of chewing areca nut. Addict Biol. 2002 Jan;7(1):115-25. https://doi.org/10.1080/13556210120091482

9. Jiang S, Dong Y. Human papillomavirus and oral squamous cell carcinoma: A review of HPV-positive oral squamous cell carcinoma and possible strategies for future. Curr Probl Cancer. 2017 Sep - Oct;41(5):323-7. https://doi.org/10.1016/i.currproblcancer.2017.02.006

10. Javed $F$, Warnakulasuriya $S$. Is there a relationship between periodontal disease and oral cancer? A systematic review of currently available evidence. Crit Rev Oncol Hematol. 2016 Jan;97:197-205. https://doi.org/10.1016/i.critrevonc.2015.08.018

11. Cancela MC, Voti L, Guerra-Yi M, Chapuis F, Mazuir M, Curado MP. Oral cavity cancer in developed and in developing countries: population-based incidence. Head Neck. 2010 Mar;32(3):357-67. https://doi.org/10.1002/hed.21193

12. Awan KH, Hegde R, Cheever VJ, Carroll W, Khan S, Patil S, et al. Oral and pharyngeal cancer risk associated with occupational carcinogenic substances: systematic review. Head Neck. 2018 Dec;40(12):2724-32. https://doi.org/10.1002/hed.25486

13. Goldstein AM, Blot WJ, Greenberg RS, Schoenberg JB, Austin DF, Preston-Martin S, et al. Familial risk in oral and pharyngeal cancer. Eur J Cancer B Oral Oncol. 1994 Sep;30B(5):319-22. https://doi.org/10.1016/0964-1955(94)90032-9

14. Ellegaard O, Wallin JA. The bibliometric analysis of scholarly production: how great is the impact? Scientometrics. 2015;105(3):1809-31. https://doi.org/10.1007/s11192-015-1645-z

15. Grant MJ, Booth A. A typology of reviews: an analysis of 14 review types and associated methodologies. Health Info Libr J. 2009 Jun;26(2):91-108. https://doi.org/10.1111/j.1471-1842.2009.00848.x

16. Mills CA, Porter MM. Tobacco smoking habits and cancer of the mouth and respiratory system. Cancer Res. 1950 Sep;10(9):539-42.

17. Waziry R, Jawad M, Ballout RA, Al Akel M, Akl EA. The effects of waterpipe tobacco smoking on health outcomes: an updated systematic review and meta-analysis. Int J Epidemiol. 2017 Feb;46(1):32-43. https://doi.org/10.1093/ije/dyw021

18. Warnakulasuriya S. Global epidemiology of oral and oropharyngeal cancer. Oral Oncol. 2009 Apr-May;45(4-5):309-16. https://doi.org/10.1016/i.oraloncology.2008.06.002

19. Keller AZ, Terris M. The association of alcohol and tobacco with cancer of the mouth and pharynx. Am J Public Health Nations Health. 1965 Oct;55(10):1578-85. https://doi.org/10.2105/AJPH.55.10.1578

20. Rothman K, Keller A. The effect of joint exposure to alcohol and tobacco on risk of cancer of the mouth and pharynx. J Chronic Dis. 1972 Dec;25(12):711-6. https://doi.org/10.1016/0021-9681(72)90006-9

21. Hassona Y, Qutachi T. A bibliometric analysis of the most cited articles about squamous cell carcinoma of the mouth, lips, and oropharynx. Oral Surg Oral Med Oral Pathol Oral Radiol. 2019 Jul;128(1):25-32.e6. https://doi.org/10.1016/j.0000.2019.01.076

22. Pena-Cristóbal M, Diniz-Freitas M, Monteiro L, Diz Dios P, Warnakulasuriya S. The 100 most cited articles on oral cancer. J Oral Pathol Med. 2018 Apr;47(4):333-44. https://doi.org/10.1111/jop.12686

23. Rivera C. Essentials of oral cancer. Int J Clin Exp Pathol. 2015 Sep;8(9):11884-94. https://doi.org/10.5281/zenodo.192487

24. Hübbers CU, Akgül B. HPV and cancer of the oral cavity. Virulence. 2015;6(3):244-8. https://doi.org/10.1080/21505594.2014.999570

25. Vainio H, Weiderpass E. Fruit and vegetables in cancer prevention. Nutr Cancer. 2006;54(1):111-42. https://doi.org/10.1207/s15327914nc5401_13

26. Levi F, Pasche C, La Vecchia C, Lucchini F, Franceschi S, Monnier P. Food groups and risk of oral and pharyngeal cancer. Int J Cancer. 1998 Aug;77(5):705-9. https://doi.org/10.1002/(SICI)1097-0215(19980831)77:5<705::AID-IJC8>3.0.CO;2-Z 
Top 100 most-cited articles on intraoral squamous cell carcinoma and its risk factors: a bibliometric study

27. Wang M, Xiao C, Ni P, Yu JJ, Wang XW, Sun H. Correlation of betel quid with oral cancer from 1998 to 2017: a study based on bibliometric analysis. Chin Med J (Engl). 2018 Aug;131(16):1975-82. https://doi.org/10.4103/0366-6999.238140

28. loannidis JP. Concentration of the most-cited papers in the scientific literature: analysis of journal ecosystems. PLoS One. 2006 Dec;1(1):e5. https://doi.org/10.1371/journal.pone.0000005

29. Patsopoulos NA, Analatos AA, loannidis JP. Relative citation impact of various study designs in the health sciences. JAMA. 2005 May;293(19):2362-6. https://doi.org/10.1001/jama.293.19.2362

30. Fontelo P, Liu F. A review of recent publication trends from top publishing countries. Syst Rev. 2018 Sep;7(1):147. https://doi.org/10.1186/s13643-018-0819-1

31. Coolidge H. Archibald cary coolidge: life and letters. United States of America: Books for Libraries; 1932.

32. Feijoo JF, Limeres J, Fernández-Varela M, Ramos I, Diz P. The 100 most cited articles in dentistry. Clin Oral Investig. 2014 Apr;18(3):699-706. https://doi.org/10.1007/s00784-013-1017-0

33. Baltussen A, Kindler CH. Citation classics in anesthetic journals. Anesth Analg. 2004;98(2):443-51. https://doi.org/10.1213/01.ANE.0000096185.13474.0A

34. Bartoli A, Medvet E. Bibliometric evaluation of researchers in the internet age. Inf Soc. 2014;30(5):349-54. https://doi.org/10.1080/01972243.2014.944731

35. Franco MC, Rice DB, Schuch HS, Dellagostin OA, Cenci MS, Moher D. The impact of gender on scientific writing: an observational study of grant proposals. J Clin Epidemiol. 2021 Aug;136:37-43. https://doi.org/10.1016/i.jclinepi.2021.01.018

36. Jamorabo DS, Chen R, Gurm H, Jahangir M, Briggs WM, Mohanty SR, et al. Women remain underrepresented in leadership positions in academic gastroenterology throughout the United States. Ann Gastroenterol. 2021;34(3):316-22. https://doi.org/10.20524/aog.2021.0597

37. Hutchinson D, Das P, Lall MD, Hill J, Fares S, Khosa F. Emergency medicine journal editorial boards: analysis of gender, h-index, publications, academic rank, and leadership roles. West J Emerg Med. 2021 Mar;22(2):353-9. https://doi.org/10.5811/westjem.2020.11.49122

38. Martín-Martín A, Thelwall M, Orduna-Malea E, Delgado López-Cózar E. Google Scholar, Microsoft Academic, Scopus, Dimensions, Web of Science, and OpenCitations' COCl: a multidisciplinary comparison of coverage via citations. Scientometrics. 2021;126:871-906. https://doi.org/10.1007/s11192-020-03690-4

39. Coelho DH, Edelmayer LW, Fenton JE. A century of citation classics in otolaryngology-head and neck surgery journals revisited. Laryngoscope. 2014 Jun;124(6):1358-62. https://doi.org/10.1002/lary.24573

40. Mattos FF, Perazzo MF, Vargas-Ferreira F, Martins-Junior PA, Paiva SM. Top 100 most-cited papers in core dental public health journals: bibliometric analysis. Community Dent Oral Epidemiol. 2021 Feb;49(1):40-6. https://doi.org/10.1111/cdoe.12572

41. Blot WJ, McLaughlin JK, Winn DM, Austin DF, Greenberg RS, Preston-Martin S, et al. Smoking and drinking in relation to oral and pharyngeal cancer. Cancer Res. 1988 Jun;48(11):3282-7. https://doi.org/10.1007/s10552-007-9026-4

42. Mello FW, Scotti FM, Melo G, Warnakulasuriya S, Guerra EN, Rivero ER. Maté consumption association with upper aerodigestive tract cancers: A systematic review and meta-analysis. Oral Oncol. 2018 Jul;82:37-47. https://doi.org/10.1016/i.oraloncology.2018.04.023 